\title{
Evaluation of heat spots occurence in Kalunga Quilombola Territory in Goiás temporal series
}

\author{
Noely Vicente Ribeiro ${ }^{1 *}$, Sara Alves ${ }^{1}$, Nilson Clementino Ferreira ${ }^{1}$
}

1 Laboratório de Processamento de Imagens e Geoprocessamento, Universidade Federal de Goiás
(Lapig/UFG), Goiânia, Brasil
*e-mail: ribeironoely@gmail.com

ABSTRACT - Wildfire occurence modeling has huge importance on environmental conservation and in the stablishment of environmental education, fiscalization and fire fighting actions. The elaboration of computational models which represent the occurence of wildfires ought to have a data and information set about these events. Currently, an important set of satelitte orbitals, equipped with surface temperature variation sensors, have been used by National Space Survey Institute (INPE) in order to monitor heat spots throughout South America. These sensors provide moderate spatial resolution data $(1 \mathrm{~km}$ to $8 \mathrm{~km}$ ), yet with high temporal resolution, until 30 minutes. These data are available for free at INPE fire database (www.inpe.br/bdqueimadas). For the project's elaboration, wildfire data were accessed on a wildfire database website, for the years between 2009 and 2017. Then, through a computation program of Geographical Information System (QGIS), the wildfire data were spatially integrated to the Kalunga Quilombola territory map. After the wildfire data spatial integration, these were analysed in monthly temporal resolution using an electronical computational program table. Then, the production of temporal series graphs were started for posterior analysis, whose tendencies were being verified, as well as the seasonal patterns. It was possible to observe that the temporal series has an expressive randomity degree with years which had large fire occurence and years with minor occurence, probably due to climate anomalies such as "El Niño". However, there is a clear seasonal pattern with a wildfire increase in June/July, an expressive increase in September and October, which are drier months. This data and information set are going to be used as an aid in spatial and temporal modeling for wildfire occurence in Kalunga Quilombola territory.

Keywords: fire monitoring, fire computational modeling, geographical information system 